\title{
Conservation of Williams pear using edible coating with alginate and carrageenan
}

\author{
Conservação de pera Williams utilizando coberturas comestíveis compostas de alginato e carragena
}

\author{
Kessiane Silva de MORAES ${ }^{1}$, Cristiane FAGUNDES ${ }^{1}$, Maria Carolina MELO ${ }^{1}$, \\ Pamela ANDREANI ${ }^{1}$, Alcilene Rodriguez MONTEIRO ${ }^{1 *}$
}

\begin{abstract}
The aim of this study was to evaluate the physical and chemical parameters of Williams pear, stored at $25^{\circ} \mathrm{C}$ for 15 days, with and without edible coating. Edible coatings prepared with alginate $2 \%$ and carrageenan $0.5 \%$ were tested. The analyses carried out on the samples were: weight loss, $\mathrm{pH}$, soluble solids, firmness, and color. The edible coatings were characterized in terms of mechanical properties, permeability, thickness, and opacity. The results show that the application of edible coatings with carrageenan and alginate in pears influenced physical and chemical characteristics such as weight loss, $\mathrm{pH}$, total soluble solids, color, and firmness of the fruit. However, the alginate coating showed the best results on pear conservation since it had lower water vapor permeability and greater tensile strength, and therefore it can be used as a protective film on these fruits.

Keywords: storage; room temperature; physicochemical analysis.
\end{abstract}

\section{Resumo}

O trabalho teve como objetivo avaliar os parâmetros físico-químicos da pera Williams, com e sem cobertura comestível, armazenada a $25^{\circ} \mathrm{C}$ por 15 dias. Foram testadas coberturas de alginato $2 \%$ e carragena $0,5 \%$. As análises realizadas nas amostras foram: perda de massa fresca, $\mathrm{pH}$, sólidos solúveis totais, firmeza e cor. As coberturas comestíveis foram caracterizadas por meio das propriedades mecânicas, de permeabilidade, espessura e opacidade. Os resultados mostraram que a aplicação de coberturas comestíveis com carragena e alginato em peras influenciou as características físico-químicas, como perda de massa fresca, $\mathrm{pH}$, sólidos solúveis totais, cor e firmeza das frutas. Entretanto, a cobertura de alginato mostrou os melhores resultados na conservação de peras. Filmes de alginato apresentaram menor permeabilidade ao vapor de água e maior tensão de ruptura, servindo como uma barreira protetora à fruta.

Palavras-chave: armazenamento; temperatura ambiente; análises físico-químicas.

\section{Introduction}

Pears are climacteric fruits, in which the major negative changes are the results of maturation. During ripening, some changes are observed in firmness, color, acidity, sugar content, and development of aroma (ALPALHAO et al., 2006).

In order to slow down the changes that occur during ripening, studies on the use of edible coatings in order to prolong the shelf life of fruits and vegetables such as strawberries (RIBEIRO et al., 2007), grapes (FAKHOURI et al., 2007), and apples have been conducted (LEE et al., 2003; OLIVAS; MATTINSON; BARBOSA-CÁNOVAS, 2007).

Edible films are used to inhibit migration of moisture, oxygen, carbon dioxide, aromas, and lipids and to improve the mechanical integrity or handling characteristics of the food (KROCHTA; DE MULDER-JOHNSTON, 1997). Edible films should have adequate mechanical strength and extensibility to maintain integrity and withstand the external stress that occurs during processing, handling, and storage (YANG; PAULSON, 2000).

These films can be obtained from different types of materials, but the most used ones are made of polysaccharides, proteins, and lipids (CHEN, 1995). Alginate is a product of interest for the preparation of films and coatings due to its colloidal properties, which include thickener, stabilizer, gelling, and suspending and film capacities (FABRA et al., 2008).

The use of carrageenan as edible films and coatings has been explored by various fields of the food industry such as its application on fresh and frozen meat, poultry and fish to prevent superficial dehydration (SHAW; SECRIST; TUOMY, 1980), ham or sausage casings (MACQUARRIE; SCHUPP; TAYLOR, 2004), granulation-coated powders, dry solid foods, and oily foods (NINOMIYA; SUZUKI; ISHII, 1997). According to Olivas and Barbosa-Cánovas (2005), some polysaccharides such as carrageenan have been used successfully in the coverage of minimally processed fruits.

Most fruits available in Brazil are marketed at room temperature justifying the interest in evaluating the quality of whole Williams pears stored at $25^{\circ} \mathrm{C}$ using edible coatings as a conservation technique. The objective of this study was to characterize edible coatings through the evaluation of mechanical properties, permeability, thickness, and opacity

Received 21/9/2011

Accepted 12/3/2012 (005481)

1 Laboratório de Propriedades Físicas de Alimentos, Departamento de Engenharia Química e Engenharia de Alimentos, Universidade Federal de Santa Catarina - UFSC, Campus Trindade, CP 476, CEP 88040-900, Florianópolis, SC, Brasil, e-mail: alcilene@enq.ufsc.br

${ }^{*}$ Corresponding author 
in addition to evaluating the changes in the physicochemical parameters of Williams pear, with or without edible coating, stored at room temperature $\left(25^{\circ} \mathrm{C}\right)$ for 15 days.

\section{Material and methods}

\subsection{Material}

Williams Pears (Pyrus communis) were obtained from a local market at the commercial ripening stage (12 to $14^{\circ} \mathrm{Brix}$ and green skin color). The coatings were made from carrageenan from Sigma Aldrich (St. Louis, USA), sodium alginate from Sigma Aldrich (Gillingham, UK), glycerol (Nuclear), and sodium hypochlorite (Vetec).

\subsection{Edible coating characterization}

$25 \mathrm{~mL}$ of film solutions were added to acrylic plates $14 \mathrm{~cm}$ in diameter and dried in an oven (TE-394/2, Tecnal, Piracicaba, Brazil) at $25^{\circ} \mathrm{C}$ for 24 hours. The gain of mass in each diffusion cell was determined by successive weighing on an analytical balance (AY 220, Shimadzu, São Paulo, Brazil) in intervals of 1 hour for 12 hours; after that it was determined 24 hours from the beginning of the experiment. Water vapor permeability was determined by the gravimetric method ASTM E96-00 described by Sarantópoulos et al. (2002). The coverage thickness was measured using a micrometer (MDC 25P, Mitutoyo, Tokyo, Japan), as an average of ten random measurements. The tensile tests were performed on a digital texture analyzer (TAXT2i, Stable Micro System, Godalming, UK) with 6 samples ( $25 \mathrm{~mm} \times$ $100 \mathrm{~mm}$ ) conditioned for 48 hours at $58 \% \mathrm{RH}$ at $25^{\circ} \mathrm{C}$. The test was conducted based on the D882-00 method (AMERICAN..., 1996) with initial distance from the clutches of $50 \mathrm{~mm}$ and tensile speed of $0.8 \mathrm{~mm} / \mathrm{s}$. The color parameters of the films were determined using a colorimeter (Miniscan EZ, HunterLab, Reston, USA), and the opacity was calculated according to Fakhouri et al. (2007).

\subsection{Preparation and application of edible coatings}

For the carrageenan coating (Sigma Aldrich, St. Louis, USA), a $0.5 \%$ aqueous solution and $0.15 \mathrm{~g}$ of glicerol was prepared according to Larotonda (2007). For the sodium alginate (Sigma Aldrich, Gillingham, UK) coating, a 2\% solution was prepared according to Meneghel, Benassi and Yamashita (2008) with modifications. The pears were sanitized in sodium hypochlorite $(100 \mathrm{ppm} / 20 \mathrm{~min})$. Next, they were divided into two batches of 15 units. The control batch (without coating) was immersed in distilled water, and the fruits of the second batch were immersed for 5 seconds in one of the filmogenic solutions $(500 \mathrm{~mL})$ at $25^{\circ} \mathrm{C}$ and kept at room temperature to allow the coating to dry. The control samples and the samples with edible coatings were stored at $25^{\circ} \mathrm{C}$ for 15 days in an incubator at relative humidity of $78 \%$.

\subsection{Characterization of pears}

Pears were characterized by physical and chemical analysis (weight loss, $\mathrm{pH}$, and soluble solids), firmness (penetration force), and color. All tests were performed in triplicate on the $1^{\text {st }}, 4^{\text {th }}, 6^{\text {th }}, 8^{\text {th }}, 11^{\text {th }}$, and $15^{\text {th }}$ days of storage.

The weight loss was determined gravimetrically using an analytical balance (AY 220, Shimadzu, São Paulo, Brazil) during the storage period (PEREIRA et al., 2006).

The pear juice was obtained by mixing $10 \mathrm{~g}$ of the sample and $100 \mathrm{~mL}$ of water with a mixer (Turbomix, Moulinex). The $\mathrm{pH}$ of pear juice was determined using a digital $\mathrm{pH}$ meter (Q400 A, Quimis, Diadema, Brazil).

The soluble solids content was determined after the compression of the fruit pulp to extract juice using a digital refractometer (AR 200, Reichert Analytical Instruments, New York, USA).

The firmness of the samples was measured by penetration force using a digital texture analyzer (TAXT2i, Stable Micro System, Godalming, UK) with a load cell of $50 \mathrm{~kg}$ and a $2 \mathrm{~mm}$ probe, test speed of $3.3 \mathrm{~mm} / \mathrm{s}$, penetration of $2 \mathrm{~mm}$, and time of 30 seconds. Ten measurements were performed for each day of analysis.

To determine the color of the samples, 8 measurements were performed in the fruit skin using a colorimeter (Miniscan EZ, HunterLab, Reston, USA) with a D65/10 $0^{\circ}$ lighting system. Lightness $(\mathrm{L})$, green to red $\left(\mathrm{a}^{*}\right)$, and blue to yellow color $\left(\mathrm{b}^{*}\right)$ were evaluated using the Hunter scale.

\subsection{Statistical analysis}

The results were evaluated by analysis of variance (ANOVA) with Statistica 6.0 (Stafsoft Inc., USA) software, and the factors that showed significant differences $(\mathrm{p} \leq 0.05)$ were submitted to Tukey's test.

\section{Results and discussion}

\subsection{Edible coating characterization}

Table 1 shows the thickness, opacity, tensile tests, and water vapor permeability (WVP) of edible coatings. The thickness of the films were $0.042 \mathrm{~mm}$ and $0.039 \mathrm{~mm}$ for the alginate and carrageenan films, respectively. Larotonda (2007), who studied carrageenan coatings produced by casting, found film thickness values of $0.09 \mathrm{~mm}$. The values were different due to the amount of filmogenic solution added to the plates in order to obtain the films. Zactiti (2004) found that calcium alginate films had a thickness of $0.097 \mathrm{~mm}$. According to the author, thickness has a great influence on the barrier properties of films. The opacity values of alginate and carrageenan showed a significant difference $(\mathrm{p} \leq 0.05)$. In the present study, the alginate and carrageenan films showed opacities of $4.52 \%$ and $6.75 \%$, respectively. The results obtained by Da Silva (2009) for pure alginate films showed $7 \%$ opacity.

The alginate edible coating showed higher tensile strength, elongation, and elastic modulus when compared to the carrageenan coating ( $\mathrm{p} \leq 0.05)$. Oliveira et al. (2006) showed elongation values of $1.9 \%$ for sodium alginate films. Pranoto, Salokhe and Raksh (2005) evaluated the mechanical properties 
of alginate-based edible film incorporated with garlic oil and found rupture tension values of $66.12 \mathrm{MPa}$ and elongation of $4.05 \%$ for films without the addition of garlic oil. Larotonda (2007) evaluated the mechanical properties of carrageenan film in different concentrations $(16.7,33.3,44.4$, and $100 \%)$ and found rupture tension values between 10 and $55 \mathrm{MPa}$, elongation between 1 and $4.5 \%$, and Young's Modulus between 10 and $25 \mathrm{MPa}$. The results show that the alginate coating had lower permeability and showed a significant difference $(\mathrm{p} \leq 0.05)$ from carrageenan coating. According to Hambleton et al. (2008), the water vapor permeability values of the alginate film were lower than those of the carrageenan film. This is probably due to ionic crosslinking in alginate films reducing the segmental mobility of the polymer.

\subsection{Characterization of pears}

The fruit weight loss values are presented in Figure 1. The loss of water in fruits is mainly related to the sweating, breathing, and storage time, and it results in wrinkling, softening of tissues, and loss of brightness making fruits more susceptible to deterioration (KADER, 1992).

The weight loss was greater for the control samples, followed by the samples with carrageenan $0.5 \%$ and alginate $2 \%$ (Figure 1). It was found that $2 \%$ alginate used in the coatings was sufficient to minimize the loss of water to the environment. These results indicate that weight loss was the lowest for the samples with alginate due to the lower water vapor permeability of this coating. Miguel et al. (2009) evaluated the effect of the film concentration on the weight loss of grapes and found that the grapes treated with $1 \%$ alginate showed the lowest losses ( $10.16 \%)$, followed by concentrations of $0.75 \%$ (11.72\%), $0.50 \%$ (11.79\%), $0.25 \%(14.14 \%)$, and the control sample (16.43\%). Larotonda (2007) studied the influence of carrageenan coating on the weight loss of cherries and found that the coating significantly reduced ( $\mathrm{p} \leq 0.05)$ weight loss of the fruits during storage when compared to that of the control sample.

The $\mathrm{pH}$ of fruit is presented in Table 2. During storage, there was a significant increase $(\mathrm{p} \leq 0.05)$ in the $\mathrm{pH}$ of the control samples and the fruits coated with alginate and carrageenan $0.5 \%$. The coated samples differed significantly $(\mathrm{p} \leq 0.05)$ of the control sample on all days evaluated. Since the control sample showed an increase in $\mathrm{pH}$ greater than that of the coated samples, this indicates that the use of coating slows down changes in the $\mathrm{pH}$ of the fruit. Comparing the edible coatings used, alginate showed smaller changes in the $\mathrm{pH}$ of the pears analyzed from the $1^{\text {st }}$ to the $15^{\text {th }}$ day of storage.

According to Chitarra and Chitarra (2005), the organic acid content decreases with maturation due to the breathing process or its conversion into sugars. Therefore, the $\mathrm{pH}$ of the fruit increases with a decrease in acidity, and thus it is used as an indicator of this variation. Fontes et al. (2008) used an edible coating of alginate on minimally processed apples stored at $2{ }^{\circ} \mathrm{C}$ for 13 days and found that the $\mathrm{pH}$ of the fruits remained unchanged during storage. Bico et al. (2009) observed a significant increase $(\mathrm{p} \leq 0.05)$ in $\mathrm{pH}$ values of fresh-cut bananas stored at $5{ }^{\circ} \mathrm{C}$ for 5 days treated with a coating of carrageenan and a preservative solution under controlled atmosphere.

The soluble solids content of the fruits are presented in Figure 2. The soluble solids (SS) content increased significantly $(\mathrm{p} \leq 0.05)$ during storage for all samples. A significant difference $(\mathrm{p} \leq 0.05)$ between the control and coated samples was observed. Samples with edible coatings showed less variation in soluble solids between the first and last days of storage when compared to that of the control sample. The application of an edible coating of $2 \%$ sodium alginate on pears may have slowed down

Table 1. Thickness, opacity, tensile tests, and water vapor permeability (WVP) of edible coatings with alginate $2 \%$ (ALG2) and carrageenan $0.5 \%$ (C05).

\begin{tabular}{lcc}
\hline \multicolumn{1}{c}{ Coating characteristics $^{(1)}$} & ALG2 & C05 \\
\hline Thickness $(\mathrm{mm})$ & $0.042 \pm 0.001^{\mathrm{a}}$ & $0.023 \pm 0.001^{\mathrm{b}}$ \\
Opacity $(\%)$ & $4.52 \pm 0.12^{\mathrm{b}}$ & $6.75 \pm 0.02^{\mathrm{a}}$ \\
Tensile strength $(\mathrm{MPa})$ & $60.96 \pm 6.20^{\mathrm{a}}$ & $23.42 \pm 4.07^{\mathrm{b}}$ \\
Elongation $(\%)$ & $2.49 \pm 0.25^{\mathrm{a}}$ & $1.10 \pm 0.26^{\mathrm{b}}$ \\
Elastic modulus $(\mathrm{MPa})$ & $37.32 \pm 2.81^{\mathrm{a}}$ & $21.83 \pm 2.65^{\mathrm{b}}$ \\
WVP $(\mathrm{g} / \mathrm{m} . P a . h) \times 10^{-7}$ & $3.42 \pm 0.12^{\mathrm{a}}$ & $4.33 \pm 0.10^{\mathrm{b}}$ \\
\hline
\end{tabular}

${ }^{(1)}$ Same letters in the same line indicate that the samples did not differ significantly $(\mathrm{p} \geq 0.05)$.

Table 2. $\mathrm{pH}$ values of control pear and pears with edible coating of alginate 2\% (ALG2) and carrageenan 0.5\% (C05) during 15 days of storage.

\begin{tabular}{cccc}
\hline \multirow{2}{*}{ Days } & \multicolumn{3}{c}{$\mathrm{pH}^{(1)}$} \\
\cline { 2 - 4 } & Control & ALG2 & $\mathrm{C} 05$ \\
\hline 1 & $4.48 \pm 0.01^{\mathrm{Ae}}$ & $4.15 \pm 0.01^{\mathrm{Ce}}$ & $4.41 \pm 0.01^{\mathrm{Bd}}$ \\
4 & $4.84 \pm 0.05^{\mathrm{Ad}}$ & $4.21 \pm 0.01^{\mathrm{Cd}}$ & $4.67 \pm 0.01^{\mathrm{Bc}}$ \\
6 & $4.86 \pm 0.03^{\mathrm{Ad}}$ & $4.26 \pm 0.02^{\mathrm{Cc}}$ & $4.75 \pm 0.04^{\mathrm{Bc}}$ \\
8 & $5.24 \pm 0.08^{\mathrm{Ac}}$ & $4.28 \pm 0.01^{\mathrm{Cc}}$ & $4.86 \pm 0.04^{\mathrm{Bb}}$ \\
11 & $5.46 \pm 0.11^{\mathrm{Ab}}$ & $4.34 \pm 0.01^{\mathrm{Cb}}$ & $4.91 \pm 0.06^{\mathrm{Bb}}$ \\
15 & $5.85 \pm 0.02^{\mathrm{Aa}}$ & $4.62 \pm 0.01^{\mathrm{Ca}}$ & $5.21 \pm 0.03^{\mathrm{Ba}}$ \\
\hline${ }^{(1)}$ Same capital letters in te
\end{tabular}

${ }^{(1)}$ Same capital letters in the same line and same lowercase letters in the same columns indicate that the samples did not differ significantly $(\mathrm{p} \geq 0.05)$.

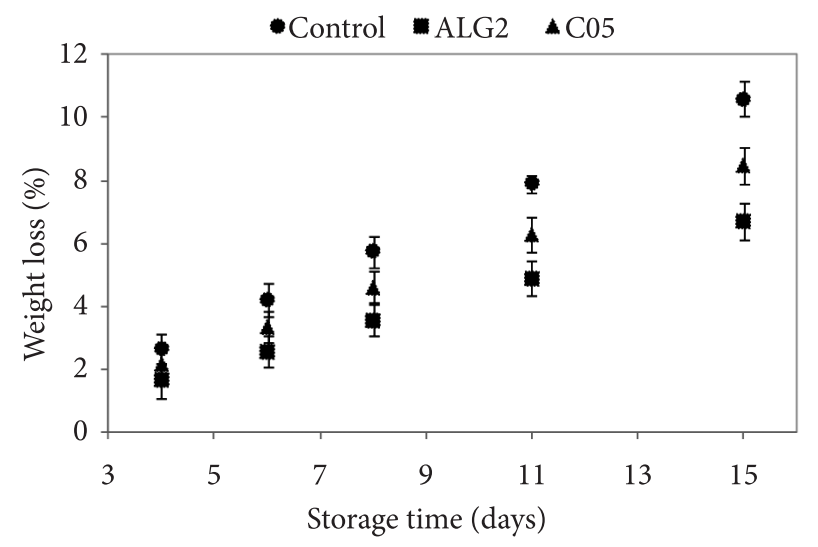

Figure 1. Weight loss of the control pear and pears coated with alginate $2 \%$ (ALG2) and carrageenan $0.5 \%$ (C05) during 15 days of storage. 
the metabolic activities of the fruit reducing the degradation of polysaccharides and changes in the soluble solids content.

Similar results were found by Fontes et al. (2008), who studied the application of coatings of alginate on fresh-cut apples stored at $2{ }^{\circ} \mathrm{C}$ for 13 days. The author describes that the content of soluble solids in the control sample and samples treated with alginate showed significant differences $(\mathrm{p} \leq 0.05)$ during storage. Bico et al. (2009) observed an increase in soluble solids content of fresh-cut bananas stored at $5{ }^{\circ} \mathrm{C}$ for 5 days treated with coating of carrageenan and a preservative solution under controlled atmosphere.

The firmness of fruit is presented in Figure 3. The penetration force values of the control sample decreased significantly $(\mathrm{p} \leq 0.05)$ from the $1^{\text {st }}$ to the $6^{\text {th }}$ day. After this period, no significant difference $(\mathrm{p} \geq 0.05)$ was observed. Samples with an edible coating of $0.5 \%$ carrageenan varied significantly $(\mathrm{p} \leq 0.05)$ during the 15 days of storage. The results of penetration force for the samples with alginate $2 \%$ did not differ significantly ( $p \geq 0.05$ ) during the storage period indicating that the edible coating used maintained the firmness of the stored pears for 15 days.

Olivas, Mattinson and Barbosa-Cánovas (2007) studied sliced apples treated with alginate stored at $5{ }^{\circ} \mathrm{C}$ for 10 days. The authors showed that the coating maintained the firmness of the apples during the storage period. According to Larotonda (2007), who analyzed cherries with an edible coating of carrageenan stored at $5{ }^{\circ} \mathrm{C}$ for 18 days, the values of firmness of the samples with and without coating were similar indicating that the coating did not influence the strength of the product.

Table 3 shows the results obtained for the color of pears. Externally, the yellowing of the skin is the greatest change that occurs during ripening (VILAS BOAS et al., 2001). Therefore, the color result is an important indication of the shelf life of fruits and vegetables. The maturation stage can be characterized subjectively by the level of skin color, which is an important parameter to predict the shelf life of fruits.

The $\mathrm{L}, \mathrm{a}^{*}$, and $\mathrm{b}^{*}$ values for the control sample varied significantly $(\mathrm{p} \leq 0.05)$ during the storage period indicating color variation from green to yellow. The control samples

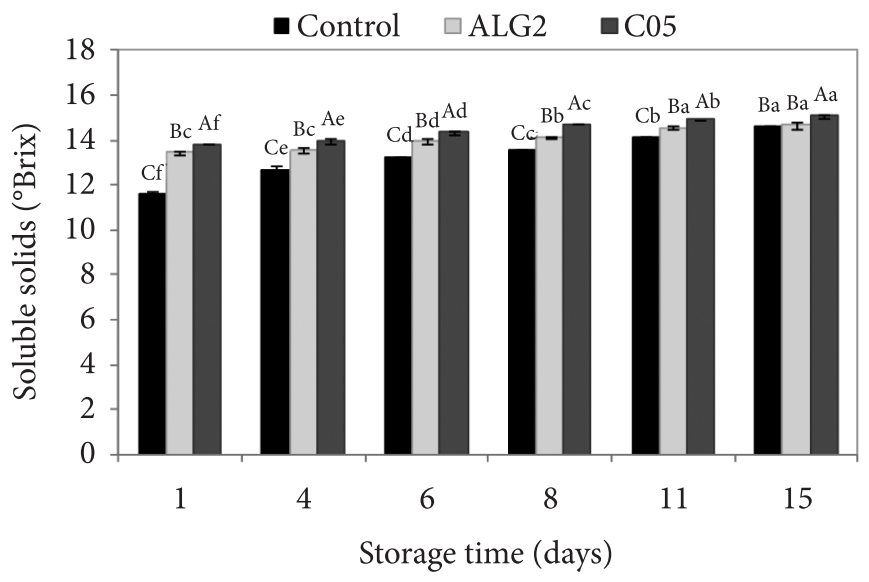

Figure 2. Soluble solids of the control pear and pears with edible coating of alginate $2 \%$ (ALG2) and carrageenan $0.5 \%$ (C05) during 15 days of storage. Same capital letters in columns of different colors and same lowercase letters in the columns of same color indicates that the samples did not differ significantly $(\mathrm{p} \geq 0.05)$.

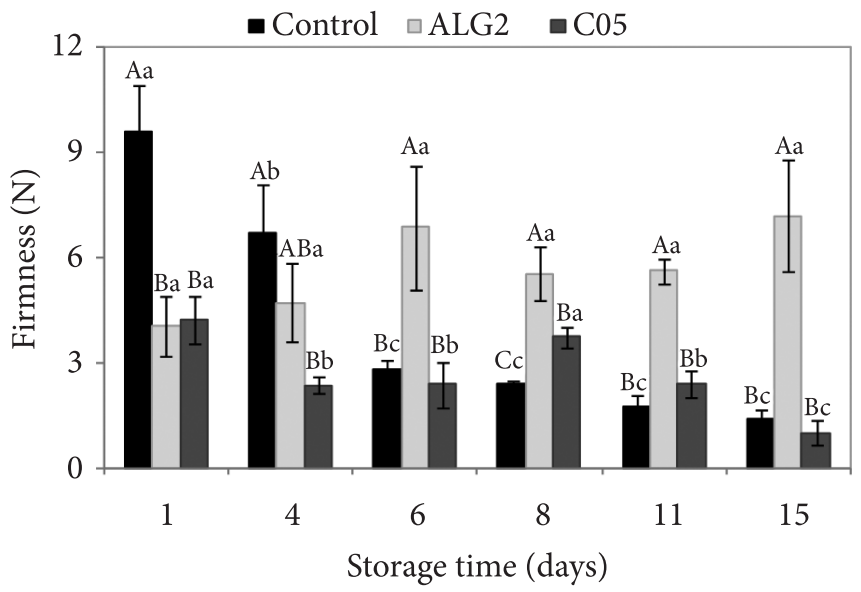

Figure 3. Firmness of the control pear and pears with edible coating of alginate 2\% (ALG2) and carrageenan 0.5\% (C05) during 15 days of storage. Same capital letters in columns of different colors and same lowercase letters in the columns of same color indicates that the samples did not differ significantly ( $\mathrm{p} \geq 0.05)$.

Table 3. Color of control pear and pears with edible coating of alginate $2 \%$ (ALG2) and carrageenan 0.5\% (C05) during 15 days of storage.

\begin{tabular}{|c|c|c|c|c|c|c|c|}
\hline \multirow{2}{*}{ Sample } & \multirow{2}{*}{ Color } & \multicolumn{6}{|c|}{ Storage time $(\text { days })^{(1)}$} \\
\hline & & 1 & 4 & 6 & 8 & 11 & 15 \\
\hline \multirow[t]{2}{*}{ Control } & $\mathrm{L}$ & $74.1 \pm 0.85^{\mathrm{Aa}}$ & $74.5 \pm 0.49^{\mathrm{Aa}}$ & $75.7 \pm 0.78^{\mathrm{Aa}}$ & $74.9 \pm 0.68^{\mathrm{Aa}}$ & $74.8 \pm 1.17^{\mathrm{Aa}}$ & $69.6 \pm 1.26^{\mathrm{Ab}}$ \\
\hline & $a^{*}$ & $-5.5 \pm 0.98^{\mathrm{Bd}}$ & $4.3 \pm 0.80^{\mathrm{Ac}}$ & $5.8 \pm 0.13^{\mathrm{Ac}}$ & $9.1 \pm 0.47^{\mathrm{Ab}}$ & $9.8 \pm 0.92^{\mathrm{Ab}}$ & $13.2 \pm 0.59^{\mathrm{Aa}}$ \\
\hline \multirow[t]{2}{*}{ ALG2 } & $\mathrm{L}$ & $70.1 \pm 0.42^{\mathrm{Aa}}$ & $67.7 \pm 0.68^{\mathrm{Cab}}$ & $63.6 \pm 0.49^{\mathrm{Cc}}$ & $66.8 \pm 0.86^{\mathrm{Bb}}$ & $60.3 \pm 0.82^{\mathrm{Bd}}$ & $58.9 \pm 1.91^{\mathrm{Bd}}$ \\
\hline & $a^{*}$ & $-2.6 \pm 1.13^{\mathrm{Ac}}$ & $-2.4 \pm 0.64^{\mathrm{Bc}}$ & $1.5 \pm 0.70^{\mathrm{Bb}}$ & $2.4 \pm 1.47^{\mathrm{Bb}}$ & $2.7 \pm 1.33^{\mathrm{Bab}}$ & $5.5 \pm 0.40^{\mathrm{Ba}}$ \\
\hline \multirow{2}{*}{$\mathrm{C} 05$} & $a^{*}$ & $-3.9 \pm 0.98^{\mathrm{Abc}}$ & $-3.6 \pm 0.48^{\mathrm{Bc}}$ & $-1.7 \pm 0.82^{\mathrm{Cb}}$ & $-1.6 \pm 0.58^{\mathrm{Cb}}$ & $4.3 \pm 0.76^{\mathrm{Ba}}$ & $4.6 \pm 0.32^{\mathrm{Ba}}$ \\
\hline & $b^{*}$ & $40.7 \pm 1.41^{\mathrm{Bd}}$ & $41.7 \pm 1.04^{\mathrm{Bc}}$ & $42.8 \pm 0.91^{\mathrm{Bbc}}$ & $43.2 \pm 0.94^{\mathrm{Bbc}}$ & $45.9 \pm 1.58^{\mathrm{Bab}}$ & $47.8 \pm 1.00^{\mathrm{Ba}}$ \\
\hline
\end{tabular}

${ }^{(1)}$ Same capital letters in the same columns for each parameter and same lowercase letters in the same line indicates that the samples did not differ significantly ( $\mathrm{p} \geq 0.05$ ). 
showed greater variation in the parameters $a^{*}$ and $b^{*}$ when compared to those of the coated samples; this result justifies the more intense yellow color of the control samples at the end of the storage period. According to Chitarra and Chitarra (2005), chlorophyll is abundant in green products and the loss of this pigment is due to its structural decomposition, mainly by changes in $\mathrm{pH}$, caused by the accumulation of organic acids in vacuoles, the activation of the chlorophyllase enzyme, and the presence of oxidizing systems. The values of $L$, $a^{*}$, and $b^{*}$ of the samples with $0.5 \%$ carrageenan coating varied significantly ( $\mathrm{p} \leq 0.05$ ) during storage. For the sample with $2 \%$ alginate, $\mathrm{L}$ values decreased significantly $(p \leq 0.05)$ during storage. In the alginate samples, the values of $a^{*}$ and $b^{*}$ varied significantly ( $\mathrm{p} \leq 0.05$ ), but this variation was lower than that observed for the control samples and the samples coated with carrageenan indicating that the coating with $2 \%$ alginate showed a better result in maintaining the green color of the fruit. Investigating cherries, Larotonda (2007), the lightness (L) values of the control sample and the samples coated with carrageenan tended to decrease during storage under refrigeration. The control sample and the coated fruits showed similar behavior indicating that the application of carrageenan coating did not slow down the senescence of cherries.

\section{Conclusions}

The application of an edible coating with sodium alginate minimized the weight loss of samples. The results showed that the use of coatings on pears reduced changes in the $\mathrm{pH}$ of the fruit. The use of alginate coating showed smaller changes in $\mathrm{pH}$ and soluble solids of the pears analyzed. Similar results were obtained for the color of pears. The penetration force results indicated that the alginate coating maintained the firmness of pears during the 15 days of storage at $25^{\circ} \mathrm{C}$. Alginate coating had the lowest water vapor permeability and highest tensile strength. Therefore, it can be used as a protective barrier on fruits. With regard to films made with carrageenan, new experiments must be carried out in order to evaluate the suspension concentrations different from those studied in this research.

\section{References}

ALPALHAO, A. et al. Efeito do 1-metilciclopropeno em pera 'Rocha' em diferentes estados de maturação armazenadas em atmosfera normal. In: SIMPÓSIO NACIONAL DE FRUTICUlTURA, 1., 2006, Alcobaça. Anais... Alcobaça: Actas Portuguesas de Horticultura, 2006. p. 232-238.

AMERICAN SOCIETY FOR TESTING AND MATERIALS - ASTM. D-882-91: Standard test method for tensile properties oh thin plastic sheeting. Philadelphia: American Society for Testing and Materials, 1996. Annual Book of ASTM.

BICO, S. L. S. et al. Combined effects of chemical dip and/or carrageenan coating and/or controlled atmosphere on quality of fresh-cut banana. Journal Food Control, v. 20, n. 5, p. 508-514, 2009. http:// dx.doi.org/10.1016/j.foodcont.2008.07.017

CHEN, H. Functional properties and applications of edible films made of milk proteins. Journal of Dairy Science, v. 78, n. 11, p. 2563-2583, 1995. http://dx.doi.org/10.3168/jds.S00220302(95)76885-0
CHITARRA, M. I. F.; CHITARRA, A. B. Pós-colheita de frutos e hortaliças: fisiologia e manuseio. 2. ed. Lavras: UFLA, 2005. 783 p.

DA SILVA, M. A. Confecção e caracterização de filmes compostos de alginato e quitosana contendo natamicina como agente antimocótico. 2009. $200 \mathrm{f}$. Tese (Doutorado em Engenharia Química)-Faculdade de Engenharia Química, Universidade Estadual de Campinas, Campinas, 2009.

FABRA, M. J. et al. Aroma barrier properties of sodium caseinatebased films. Biomacromolecules, v. 9, n. 5, p. 1406-1410, 2008. PMid:18361517. http://dx.doi.org/10.1021/bm701363p

FAKHOURI, F. M. et al. Filmes e coberturas comestíveis compostas à base de amidos nativos e gelatina na conservação e aceitação sensorial de uvas Crimson. Ciência e Tecnologia de Alimentos, v. 27 , n. 2 , p. $369-375,2007$. http://dx.doi.org/10.1590/S010120612007000200027

FONTES, L. C. B. et al. Conservação de maçã minimamente processada com o uso de películas comestíveis. Ciência e Tecnologia de Alimentos, v. 28, n. 4, p. 872-880, 2008. http://dx.doi.org/10.1590/ S0101-20612008000400017

HAMBLETON, A. et al. Protection of active aroma compound against moisture and oxygen by encapsulation in biopolimeric emulsion-based edible films. Biomacromolecules, v. 9, n. 3, p.1058-1063, 2008. PMid:18257554. http://dx.doi.org/10.1021/ bm701230a

KADER, A. A. Postharvest technology of horticultural crops. 12th ed. Oakland: University of California, Division of Agriculture and Natural Resources, 1992. 296 p.

KROCHTA, J. M.; DE MULDER-JOHNSTON, C. Edible and biodegradable polymer films: challenges and opportunities. Food Technology, v. 51, n. 2, p. 61-77, 1997.

LAROTONDA, F. D. S. Biodegradable films and coatings obtained from carrageenan from Mastocarpus stellatus and starch from Quercus súber. 2007. $260 \mathrm{f}$. Thesis (Doctor of Philosophy in Chemical and Biological Engineering)-Faculty of Engineering, University of Porto, Porto, 2007.

LEE, J. Y. et al. Extending shelf-life of minimally processed apples with edible coatings and antibrowning agents. LWT - Food Science and Technology, v. 36, n. 3, p. 323-329, 2003. http://dx.doi.org/10.1016/ S0023-6438(03)00014-8

MACQUARRIE, R.; SCHUPP, K.; TAYLOR, P. Edible casing film formulation. US n. PI 6730340 B1. 2004.

MENEGHEL, R. F. A.; BENASSI, M. T.; YAMASHITA, F. Revestimento comestível de alginato de sódio para frutos de amora-preta (Rubus ulmifolius). Ciências Agrárias, v. 29, n. 3, p. 609-618, 2008.

MIGUEL, A. C. A. et al. Pós-colheita de uva 'Itália' revestida com filmes à base de alginato de sódio e armazenada sob refrigeração. Ciência e Tecnologia de Alimentos, v. 29, n. 2, p. 277-282, 2009. http:// dx.doi.org/10.1590/S0101-20612009000200006

NINOMIYA, H.; SUZUKI, S.; ISHII, K. Edible film and method of making same. US n. PI 5620757. 1997.

OLIVAS, G. I.; BARBOSA-CÁNOVAS, G. V. Edible coatings for fresh-cut fruits. Critical Reviews in Food Science and Nutrition, v. 45, n. 7 , p. 657-670, 2005. PMid:16371333. http://dx.doi. org/10.1080/10408690490911837

OLIVAS, G. I.; MATTINSON, D. S.; CÁNOVAS, G. V. Alginate coatings of minimally processed 'Gala' apples. Postharvest Biology and Technology, v. 45, n.1, p. 89-96, 2007. http://dx.doi.org/10.1016/j. postharvbio.2006.11.018 
OLIVEIRA, A. F. et al. Desenvolvimento, caracterização e aplicação de biofilmes obtidos a partir de carboximetilcelulose e alginato de sódio na liberação de nutrientes. In: CONGRESSO BRASILEIRO DE ENGENHARIA E CIÊNCIA DOS MATERIAIS, 17., 2006, Foz do Iguaçu. Anais... Foz do Iguaçu: Instituto de Pesquisas Energéticas e Nucleares, 2006. p. 7858-7869.

PEREIRA, T. et al. Influência das condições de armazenamento nas características físicas e químicas de goiaba (psidium guajava), cv. Cortibel de polpa branca. Revista Ceres, v. 53, n. 306, p. 276-284, 2006.

PRANOTO, Y.; SALOKHE, V. M.; RAKSH, S. K. Physical and antibacterial properties of alginate-based edible film incorporated with garlic oil. Food Research International, v. 38, n. 3, p. 267-272, 2005. http://dx.doi.org/10.1016/j.foodres.2004.04.009

RIBEIRO, C. et al. Optimization of edible coating composition to retard strawberry fruit senescence. Postharvest Biology and Technology, v. 44, n. 1, p. 63-70, 2007. http://dx.doi.org/10.1016/j. postharvbio.2006.11.015
SARANTÓPOULOS, C. I. G. L. et al. Embalagens plásticas flexíveis - principais polímeros e avaliação de propriedades. Campinas: CETEA/ITAL, 2002. 267 p.

SHAW C. P.; SECRIST, J. L.; TUOMY, J. M. Method of extending the storage life in the frozen state of precooked foods and products thereof. US n. PI 4196219. 1980.

VILAS BOAS, E. V. B. et al. Características da fruta. In: MATSUURA, F. C. A. U.; FOLEGATTI, I. S. Banana: pós-colheita. Brasília: Embrapa Informação Tecnológica, 2001, p.15-19.

ZACTITI, E. M. Desenvolvimento e caracterização de filmes biodegradáveis de alginato de cálcio sem e com sorbato de potássio. 2004. $154 \mathrm{f}$. Tese (Doutorado em Engenharia Química)Faculdade de Engenharia Química, Universidade Estadual de Campinas, Campinas, 2004.

YANG, L.; PAULSON, A. T. Effects of lipids on mechanical and moisture barrier properties of edible gellan film. Food Research International, v. 33, n. 7, p. 571-578, 2000. http://dx.doi. org/10.1016/S0963-9969(00)00093-4 